Relations industrielles

Industrial Relations

\title{
Industrial Safety
}

Volume 1, numéro 7, mars 1946

URI : https://id.erudit.org/iderudit/1023941ar

DOI : https://doi.org/10.7202/1023941ar

Aller au sommaire du numéro

Éditeur(s)

Département des relations industrielles de l’Université Laval

ISSN

0034-379X (imprimé)

1703-8138 (numérique)

Découvrir la revue

Citer cet article

(1946). Industrial Safety. Relations industrielles / Industrial Relations, 1(7), 5-5.

https://doi.org/10.7202/1023941ar

Tous droits réservés (C) Département des relations industrielles de l’Université Laval, 1946
Ce document est protégé par la loi sur le droit d'auteur. L’utilisation des services d'Érudit (y compris la reproduction) est assujettie à sa politique d'utilisation que vous pouvez consulter en ligne.

https://apropos.erudit.org/fr/usagers/politique-dutilisation/
Cet article est diffusé et préservé par Érudit.

Érudit est un consortium interuniversitaire sans but lucratif composé de l'Université de Montréal, l'Université Laval et l'Université du Québec à

Montréal. Il a pour mission la promotion et la valorisation de la recherche.

https://www.erudit.org/fr/ 


\section{INDUSTTRIAL SAFETY}

Beveridge, in his recapitulation of the needs of the British Nation, outlined a plan having for its object the safety of the individual : Unemployment Insurance ; Sick Benefits ; Old Age Pension and finally Life Insurance. This was a further proof that humanity strives, at least, for palliatives to secular unhappiness, the memory of which cannot be taken away. In spite of the efforts of the best economists, there have always been mass unemployment periods; sickness cannot be avoided; old age is also unavoidable.

We have another story inasmuch as the industrial accident is concerned; in this field, compensation gradually dissappears to be replaced by prevention. In the domain of health, some mention, with courage, preventive medecine as a possible and desirable achievement. Industrial safety has already become the result of the precise enforcement of scientific principles which are more and more accepted everywhere.

Better clarification will be obtained if we summarize our achievements in the fields of industrial safety. It will then be easier to draw conclusions and to arrive at practical means to give better efficiency to preventive methods, to group more citizens of good will and to make out of the industrial plant a place where the workman earns his living safely.

\section{The Quebec Achievements IN The FIELd of SAFETy}

The first legislation dealing with accident prevention in North America dates back to 1867 ; the State of Massachusetts' Legislative Assembly in the very years of the coming into being of the Canadian Confederation, formed a Labour Inspection Service. Ten years later, the employers of that State became legally bound to guard effectively dangerous machineries. The only other government in North America before Quebec to legislate indirectly in this field was the Alabama State authority which, together with Massachusetts, adopted in 1885 a legislation imposing upon management some responsibilities in case of accident ; we still find in such legislative measures the principles of our present Workmen's Compensation Acts.

The Quebec Government, together with that of Ontario, enforced the recommendations of a Federal Parliamentary Commission and adopted in 1885, the Manufacturing Establishments Act which became, after many revisions, our present Industrial and Commercial Establishments Act : it is our basic legislation dealing with safety and accident prevention in manufacturing concerns. Its scope is very broad and the inspection staff, numerous and ever gaining in experience, lives up to its tasks. It is, consequently, to be concluded that the Province of Quebec, in the field of accident prevention legislation, has not been backward.
Management and Labour have quickly realized that they also have responsibilities ; employers, on account of a well founded desire to cut down accidents derived from the functioning of their industry and also to eliminate a loss of money and energy ; workers, in order to stop living in manufacturing establishments in the fear of industrial accidents and of their disastrous consequences. The first practical step to fulfill that desire took the shape of the constitution of Accident Prevention Associations of Employers, and later on, was followed by a common effort of Management and Labour in the field of accident prevention ; in Quebec, the example set down in United States was followed. In 1915 a group of enthusiastic citizens went ahead with the constitution of the American National Safety Council, following the adoption of legislation dealing with Workmen's Compensation; in Quebec, the enforcement of our Workmen's Compensation Act, sixteen years ago, was almost immediately followed by the constitution of the Quebec Industrial Accidents Prevention Association. This group benefitting by financial aid from the Workmen's Compensation Board is more and more active. Its scope of activities comprises namely Education and Propaganda.

Various surveys have shown that in many plants, Joint Prevention Accident Committees are operating. Workers partake in educational drives, are on the lookout for accident risks and make appropriate recommendations ; experience has definitely proved that such efforts are successful.

Just as on the general level of industrial relations, here again we find a tripartite cooperation :

$1^{\circ}$ From management which aside from human reasons, is anxious to reach its legitimate objective to cut down production cost to a strict minimum by a voiding excessive and useless levies to the common accident compensation funds ;

$2^{\circ}$ From labour desirous of safety and untortunately too well aware, directly or indirectly, of the consequences of an industrial accident for the worker and his dependents ;

$3^{\circ}$ From the State, which, for the common good, has for its duties to draft and enforce safety standards, to act on behalf of a group of employers not safety minded and to compel objectors to follow an essentially social and necessary movement.

Just as in the field of industrial relations, the second world-wide struggle has given us a lesson in the scope of industrial safety. The necessity in North America for a total war effort, which necessitated an always enlarging production and requiring State intervention to do away with stoppages of work, has also increased the desire to eliminate the individual stoppage of work following an accident. Such lesson will achieve its purpose and we will soon be able to appreciate its consequences. 